\title{
98 \\ AGROBACTERIUM TUMEFACIENS-MEDIATED TRANSFORMATION AND REGENERATION OF MUSKMELON (CUCUMIS MELO L.)
}

\author{
Eissa Ahmed Eissa \\ Department of Genetics, Faculty of Agriculture, Fayoum University, \\ Egypt.
}

ABSTRACT:

Agrobacterium-based plasmid vectors allow the transformation of a wide range of plant species by capitalizing on a natural bacterial system to introduce DNA into the nuclear genome of plants. A regeneration protocol for muskmelon (Cucumis melo cv. Hales Best Jumbo) was established using segments of cotyledon as explants, and combined this protocol with $A$. tumefaciens-mediated transformation to produce transgenic muskmelon plants. Cotyledon explants excised from 4day-old seedlings of muskmelon and cut into four segments after removed the edges of the cotyledons, co-cultivated with $A$. tumefaciens strain LBA4404 harboring binary pRGG bar plasmid. The plasmid contained phosphinothricin acetyl transferase gene (bar) as selectable marker for herbicide resistance (glufosinat ammonium, lindán) and $\beta$-glucuronidase gene (gusA) as reporter for $20 \mathrm{~min}$. Then, transferred to regeneration medium, MS medium supplemented with different combinations of plant growth regulators $(\mathrm{pH} \mathrm{5.0)}$, and incubated in a growth room at $25^{\circ} \mathrm{C}$ with a photoperiod of $16 \mathrm{~h}$ light $/ 8 \mathrm{~h}$ dark for 3 days. An overnight bacterial culture and low $\mathrm{pH}$ medium (5.0) used during co-cultivation, to improve the transformation efficiency. For shoot induction, explants were transferred onto MS medium contained different combinations of plant growth regulators with $\mathrm{pH} 5.8$, and $500 \mathrm{mg} / \mathrm{l}$ claforan (cefotaximum) was added to the medium, to prevent the growth of Agrobacterium. The elimination of the Agrobacterium was the key of successful regeneration and transformation after co-cultivation. After co-cultivation on MS medium with a low $\mathrm{pH}$, explants were transferred to selective medium, with higher $\mathrm{pH} 5.8$, containing $500 \mathrm{mg} / \mathrm{l}$ claforan and glufosinat ammonium in concentrations ranged from 0 to $10 \mathrm{mg} / \mathrm{l}$ $(0,1,2,3,4,5,8$ and $10 \mathrm{mg} / \mathrm{l})$ to know the optimum selective concentration during shoot formations. The results indicated that, MS medium supplemented with $1.05 \mathrm{mg} / \mathrm{l}$ indole-3-acetic acid (IAA)+0.6 mg/l 6-benzyladenine (BA)+0.24 mg/l abscisic acid (ABA) ranked the best in shoot formations. Shoots formed from co-cultivated cotyledons with Agrobacterium died under the conditions of high concentration more than $3 \mathrm{mg} / \mathrm{l}$ glufosinat ammonium. The medium was changed every two weeks till shoots were induced. All shoots rooted on MS medium supplemented with $0.3 \mathrm{mg} / \mathrm{l}$ indole-3-butyric acid (IBA). The expression of the introduced gene construct was confirmed by GUS staining of callus and shoot segments. Finally, transgenic muskmelon plants were produced efficiently by inoculating pieces of cotyledons as explants with $A$. tumefaciens strain LBA4404 harboring pRGG

Fayoum J. Agric. Res. \& Dev., Vol. 20, No. 2, July, 2006 
bar plasmid. The methods have been used to develop a more efficient transformation and regeneration procedures by useful genes, such as herbicide-resistance, that can be introduced into muskmelon by indirect insertion of such genes using the genetic engineering approach.

Key words: Muskmelon; Cucumis melo cv. Hales Best Jumbo; transformation; regeneration; Agrobacterium-mediated; herbicide; glufosinat ammonium resistance; selection; GUS expression.

\section{INTRODUCTION}

A. tumefaciens is a soil bacterium. It is pathogenic to a range of dicot plant species, causing the formation of tumors close to infection sites. Genes required to establish a tumors and to bring about opine biosynthesis are transferred from Agrobacterium and hence this bacterium has been called nature's genetic engineer (Hellens et al., 2000). The use of herbicides to control weeds allows growers to practice more efficient crop management, together with improving yields. Several classes of herbicides can be effectively used for broad-spectrum weed control, but these are either nonselective, killing also the crop plants, or they significantly injure some crops at the application rates required. The development of herbicide-tolerant cultivars is one way in which crops can be protected from herbicide damage. Three general methods have been used to generate herbicide-tolerant crops: germplasm screening (mutant isolation by conventional breeding), in vitro selection (mutant isolation in cell cultures) and direct or indirect insertion of herbicide-tolerant genes using the genetic engineering approach (creating mutants) (Hinchee et al., 1993). The genetic transformation of melon has become a subject of commercial importance, due to the acute need to engineer herbicide phosphinothricin resistances into muskmelon which do not exist in the current gene pool used for breeding. A cardinal part of the genetic engineering process of plants is to place the new genetic information into the plant cells that will regenerate, as only linkage of the regeneration and transformation processes can produce transformed plants.

In melon, plant regeneration via shoot organogenesis and somatic embryogenesis from cotyledon, leaf and hypocotyls explants was reported by several authors. Regeneration of plants of Cucumis melon has been reported from cotyledonary explants (Moreno et al., 1985; Niedz et al., 1989; Fang and Grumet, 1990; Vallés and Lasa, 1994; Szalai, 1996; Bordas et al., 1997; Bársony et al., 1999; Gaba et al., 2000 and Guis et al., 2000), leaf explants (Yadav et al., 1996), hypocotyls explants (Kathal et al., 1986), and protoplast-derived calli (Debeaujon and Branchard, 1991). Also, Ezura and Oosawa (1994) regenerated plantlets in two cultivars of melon via somatic embryogenesis.

However, the application of Agrobacterium-based transformation systems for foreign gene transfer into muskmelon has been demonstrated only in a few studies (Fang and Grumet, 1990; Vallés and Lasa, 1994; Gaba et al., 2000 and Guis et al., 2000). The gene encoding salt tolerance (Bordas et al., 1997) have been expressed in transgenic melon plants. Transferring cucumber mosaic virus-white leaf strain coat protein gene into Cucumis melo L. (Gonsalves et al., 1994) have been evaluated in transgenic plants. However, except for salt tolerance and protection against infections by

Fayoum J. Agric. Res. \& Dev., Vol. 20, No. 2, July, 2006 
the virus strain, other potentially useful agronomic traits have not been engineered into melon. On the basis of research by Orts et al., (1987) and their observations, cultivar specific differences exist in regeneration and transformation efficiency in muskmelon. Transformation of melon is still regarded as a difficult problem. Our own experience and discussions with colleagues around the world have suggested that perhaps only a few cultivars may be relatively easy to transform. It is well known that genotype limits the range of genetic transformation (Mackay et al., 1989). To date, most of the research has been concentrated on the cultivar Hales Best. Therefore this cultivar was chosen as experimental material.

Our objective was to develop a genetic transformation and regeneration systems that would permit the introduction of desirable gene(s) such as herbicide resistance into muskmelon. We have combined an efficient regeneration system with Agrobacterium-mediated gene transfer, and recovered transgenic muskmelon plants.

\section{MATERIALS AND METHODS}

\section{Plant material, binary vectors and bacterial strain:}

In these experiments, mature seeds from the Hales Best Jumbo, muskmelon cultivar were used. Seeds were obtained from the Vegetable Crop Research Institute, Budatétény, Hungary. The seeds coats were removed and seeds were sterilized by treating in $15 \%$ chlorox $(5.25 \%$ sodium hypochlorite) for $15 \mathrm{~min}$. They were rinsed three times with sterile distilled water and dried up with sterile filter paper. The seeds were germinated on MS medium (Murashige and Skoog, 1962) without any plant growth regulators, solidified with $2 \mathrm{~g} / \mathrm{l}$ phytagel, and incubated in thermostatic box at $32^{\circ} \mathrm{C}$ for two days, then transferred to the tissue cultures growth room at $25^{\circ} \mathrm{C}$ under a $16 \mathrm{~h}$ (light) $/ 8 \mathrm{~h}$ (dark) regime provided by cool-white fluorescent lamps. The $\mathrm{pH}$ of the germination medium was adjusted to 5.8 with $\mathrm{KOH}$ or $\mathrm{NaOH}$ before autoclaving. This in vitro culture method was used to provide explant sources in the all experiments. Four-day-old green expanded cotyledons grown under these conditions were used in the regeneration and transformation experiments. Genetic transformation, has been performed using the LBA4404 A. tumefaciens strain containing the binary vector pRGG bar plasmid. Dr. István Nagy, Agricultural Biotechnology Center, Gödöllő, Hungary, provided the bacterial strain. The plasmid harbored two genes, the phosphinothricin acetyl transferase gene (bar), as selectable marker for herbicide resistance, glufosinat ammonium- lindán (AgrEvo $\mathrm{GmbH}$, Berlin), and the $\beta$-glucuronidase gene (gusA) as reporter-coded $\beta$-glucuronidase. A. tumefaciens was grown and maintained on $\mathrm{AB}$ medium (Lichtenstein and Draper, 1986).

Co-cultivation, plant regeneration and selection:

Excised-4-day old cotyledons were cut on all around the edges with a dull scalpel blade (to maximize wounding), and cut into four segments. Then, these segments of cotyledon were soaked in fresh overnight suspension culture of Agrobacterium for 20 min, blotted dry with sterile filter paper to remove the excess of bacteria, and transferred to regeneration MS medium supplemented with different combinations of plant growth regulators (IAA, $\mathrm{BA}, \mathrm{ABA}$ and TDZ) and $3 \%$ sucrose, (pH 5.0). Co-cultivate explants were incubated in growth room at $25^{\circ} \mathrm{C}$ with photoperiod of $16 \mathrm{~h}$ light $/ 8 \mathrm{~h}$ dark for 3 days. After co-cultivation with Agrobacterium, explants were rinsed in sterile

Fayoum J. Agric. Res. \& Dev., Vol. 20, No.2, July, 2006 
distilled water to remove excess bacteria and then washed in $500 \mathrm{mg} / \mathrm{l}$ claforan solution for 20 min (to eliminate bacterial carry over), and then put into sterile distilled water to remove the rest of excess bacteria on the surfaces. Finally, cotyledonary pieces were blotted dry with sterile filter paper. In order to induce shoot formations, explants were transferred onto MS medium contained the same combinations of plant growth regulators $(\mathrm{pH}$ 5.8 ), and $500 \mathrm{mg} / \mathrm{l}$ claforan added to the medium, to prevent the growth of Agrobacterium. To obtain the optimum selective concentration of glufosinat ammonium, explants were kept on medium containing $0-10 \mathrm{mg} / \mathrm{l}$ glufosinat ammonium during shoot formations. Segments of cotyledon without Agrobacterium infections were used as control during all the experiments in order to confirm the effect of the selective medium and the genetic transformation. Well formed leafy shoots were cut and transferred into MS medium containing $0.3 \mathrm{mg} / \mathrm{l} \mathrm{IBA}$ for rooting.

Assay for $\beta$-glucuronidase activity:

The expression of the $\beta$-glucuronidase gene was assayed histologically in the calli and transformed plant tissues regenerated on selective medium. GUS assay was performed essentially as described by Jefferson et al., (1987). Prior to performing GUS assays, plants were transferred to antibiotic-free medium to ensure that the material was Agrobacterium free. Under these conditions, without antibiotics, no bacterial growth was observed in any of the subsequent culture transfers. Small portions of calli or young plant tissues were incubated over-night in a staining buffer in a thermostat at $37^{\circ} \mathrm{C}$ using 5-bromo-4-cloro-3-indolyl glucuronide (X-Gluc). The mechanism of GUS-test is based on a colour reaction. The gusA gene expression was confirmed by adding X-Gluc to stain transformed plant tissues to blue colour.

\section{RESULTS AND DISCUSSION}

\section{Influence of cotyledon development stage on shoot formations:}

It was observed that the seeds surfaces-disinfected in $15 \%$ chlorox for 15 min exhibited 85\% normal seedlings without any infections. In addition, seedlings grew better, giving rise to robust cotyledons. In preliminary experiments, it was demonstrated that the stage of cotyledons development influenced the shoot formations. As shown in Table 1, when cotyledons being half-opened and used as source of cotyledon segments, produced a higher of shoot numbers than the other stages. Explants from young or full opened cotyledons gave few shoots. In general, seeds were kept in thermostatic box in the dark at $32^{\circ} \mathrm{C}$ for 2 days. In this case, obtained cotyledons were easy to meet the requirements of regeneration and transformation. On the other hand, the results of Szalai (1996) indicated that shoot formation and regeneration of muskmelon plants could be obtained by using 8 day old cotyledons as explants.

Table 1. Influence of cotyledon development as source of explants cultured onto MS medium containing $(1.0 \mathrm{mg} / \mathrm{l} \mathrm{IAA}+0.6 \mathrm{mg} / \mathrm{l} \mathrm{BA}+0.24 \mathrm{mg} / \mathrm{l} \mathrm{ABA})$ on callus and shoot formations.

\begin{tabular}{|c|c|c|c|}
\hline $\begin{array}{c}\text { Development stage } \\
\text { of cotyledon }\end{array}$ & $\begin{array}{c}\text { Number of } \\
\text { explants }\end{array}$ & Number of callus & Number of shoots \\
\hline No-opening & 120 & 112 & 5 \\
Half-opening & 120 & 116 & 23 \\
Full-opening & 120 & 113 & 2 \\
\hline
\end{tabular}

Fayoum J. Agric. Res. \& Dev., Vol. 20, No. 2, July, 2006 
AGROBACTERIUM TUMEFACIENS-MEDIATED

Table 2. Influence of different combinations of plant growth regulators on callus and shoot formations from cotyledon pieces cultured on MS medium.

\begin{tabular}{|c|c|c|c|}
\hline $\begin{array}{l}\text { MS medium with growth } \\
\text { regulators }\end{array}$ & $\begin{array}{l}\text { Number of } \\
\text { Explants }\end{array}$ & $\begin{array}{c}\text { Number of Explants } \\
\text { with callus }\end{array}$ & $\begin{array}{c}\text { Number of Explants } \\
\text { with shoots }\end{array}$ \\
\hline $\begin{array}{c}0.9 \mathrm{mg} / \mathrm{l} \text { IAA+0.6 } \mathrm{mg} / \mathrm{l} \\
\mathrm{BA}+0.24 \mathrm{mg} / \mathrm{l} \mathrm{ABA}\end{array}$ & 350 & 331 & 0 \\
\hline $\begin{array}{l}1.0 \mathrm{mg} / \mathrm{l} \text { IAA+0.6 } \mathrm{mg} / \mathrm{l} \\
\mathrm{BA}+0.24 \mathrm{mg} / \mathrm{l} \mathrm{ABA}\end{array}$ & 350 & 326 & 19 \\
\hline $\begin{array}{l}1.05 \mathrm{mg} / \mathrm{l} \mathrm{IAA}+0.6 \mathrm{mg} / \mathrm{l} \\
\mathrm{BA}+0.24 \mathrm{mg} / \mathrm{l} \mathrm{ABA}\end{array}$ & 350 & 329 & 31 \\
\hline $\begin{array}{ccc}1.5 \mathrm{mg} / \mathrm{l} & \mathrm{IAA}+1.0 \mathrm{mg} / \mathrm{l} \\
\mathrm{TDZ}+0.26 \mathrm{mg} / \mathrm{l} \mathrm{ABA} & \end{array}$ & 63 & 58 & 0 \\
\hline $2.4 \mathrm{mg} / 1 \mathrm{IAA}+0.5 \mathrm{mg} / \mathrm{l} \mathrm{BA}$ & 63 & 60 & 0 \\
\hline
\end{tabular}

Influence of different combinations from plant growth regulators on shoot formations:

It has already been established by Niedz et al., (1989) and Fang and Grumet (1990) that melon (Cucumis melo cv. Hales Best Jumbo) cotyledonary explants cultured onto MS medium supplemented with $5 \mu \mathrm{M}$ IAA $+5 \mu \mathrm{M}$ 6-benzylaminopurine (BAP) produced shoot buds that can be used for regeneration of plants. In the present investigation, cotyledon explants were cultured onto MS medium supplemented with different combinations of plant growth regulators as shown in Table 2. With the exception of MS medium contained $(1.0 \mathrm{mg} / \mathrm{l} \mathrm{IAA}+0.6 \mathrm{mg} / \mathrm{l} \mathrm{BA}+0.24 \mathrm{mg} / \mathrm{l}$ $\mathrm{ABA})$ or $(1.05 \mathrm{mg} / \mathrm{l} \mathrm{IAA}+0.6 \mathrm{mg} / \mathrm{l} \mathrm{BA}+0.24 \mathrm{mg} / \mathrm{l} \mathrm{ABA})$, callus formed only at the cut surfaces of cotyledon segments. There were significant differences in regeneration among different combinations of plant growth regulators (Table 2). Only a kind of growth regulator combinations (1.05 mg/l IAA+0.6 $\mathrm{mg} / \mathrm{l} \mathrm{BA}+0.24 \mathrm{mg} / \mathrm{l} \mathrm{ABA}$ ) ranked the best in shoot formations induction (Fig. 1). So, this kind of plant growth regulator combinations was used in the all subsequent experiments. There were changes in IAA concentrations $(0.90$, $1.00,1.05,1.50$ and $2.40 \mathrm{mg} / \mathrm{l}$ ), BA replaced by thidiazuron (TDZ) in the regeneration medium, and other medium without $\mathrm{ABA}$, whereas other plant growth regulators kept unchanged as in Table 2. The presence of abscisic acid significantly increased the number of explants producing shoot buds. In MS medium contained 1.0 and $1.05 \mathrm{mg} / \mathrm{l} \mathrm{IAA}$, it was demonstrated that, such plant growth regulators were used to obtain the best number of cotyledon explants with shoot formations as shown in Table 2, the number of regenerated shoots per each segment of cotyledons ranged from 1 to 10 . Previous reports demonstrated that various cytokinins and auxins stimulated morphogenesis in C. melo. Moreno et al., (1985) found that a combination of (kinetin and IAA) stimulated plant regeneration, while Niedz et al., (1989) found that BA was more effective than kinetin in inducing organogenesis and TDZ were less effective for shoot differentiation from melon cotyledons than BA. The best results of regeneration from melon, Hales Best Jumbo which obtained by Yadav $\boldsymbol{e t}$ al., (1996) by using $3-4 \mathrm{~cm}$ diameter leaves excised pot grown greenhouse or growth chamber plants and cultured on MS medium with $(5 \mu \mathrm{M}$ IAA $+5 \mu \mathrm{M}$ BA+1 $\mu \mathrm{M}$ ABA, $30 \mu \mathrm{M}$ silver nitrate and $2.6 \mathrm{~g} / 1$ phytagel). On MS medium with combinations of $(2.4 \mathrm{mg} / \mathrm{l} \mathrm{IAA}+2.5 \mathrm{mg} / \mathrm{l}$ BA), high frequency of muskmelon variety hógolyó organogenesis was achieved (Bársony et al., 1999). In the present study, there was a change in

Fayoum J. Agric. Res. \& Dev., Vol. 20, No.2, July, 2006 
IAA concentration from $0.90 \mathrm{mg} / 1$ to $2.40 \mathrm{mg} / \mathrm{l}$ as shown in Table 2. For roots induction and plantlet regenerations, when the leafy regenerated shoots were well formed, they were excised and cultured directly in root induction medium, MS supplemented with $0.3 \mathrm{mg} / \mathrm{l} \mathrm{IBA}$. Callus were at first formed on the basis of shoots, and then roots were obtained and grew inside medium. The forming of roots took about three weeks. Regeneration is a comprehensive result caused by multiple factors, among which plant growth regulators played the most important role. As known, growth and reproduction in plants are regulated by growth regulators inside the plants. With the differentiation of the cells, small buds were observed at first under the light microscope before shoot formations and gradually developed into shoots.

\section{Transformation:}

Currently, numerous transformation methods are available. They can be divided into two main groups, indirect and direct ones. The indirect methods of plant transformation are based on the introduction of a plasmidcarrying gene construct into the target cell by means of bacteria- $A$. tumefaciens or A. rhizogenes. Direct methods do not use bacteria cells as mediators. Agrobacterium-mediated transformation is the main method used in the field of biotechnology, where the most often applied direct methods are protoplast transformation or microprojectile bombardment. In the case of Agrobacterium-mediated transformation, the efficiency for monocots is still unsatisfactory. However, in recent years, it has become the method of choice for this group of plants (Nadolska-Orczyk et al., 2000). One of the most effective means of gene transfer into dicot plants is to utilize the natural transformation mechanism of A. tumefaciens. We have developed a regeneration protocol, which, when combined with the use of Agrobacterium, allows relatively high frequency of transformed plants. The protocol was developed using Hales Best Jumbo, a generally used muskmelon variety, from which transformed plants have already been obtained, (Fang and Grumet, 1990 and Gaba et al., 2000). However few successful transformation with this or other methods have been reported. The successful transformation, to some extent, is dependent on the fact that during cocultivation, plasmid are capable of entering the aimed plant cells with ease. The site of the induction of the organogenesis is very important although it has not been investigated carefully, as in case of Agrobacterium-mediated plant transformation the contact between plant cell and bacteria mostly occur on wounded surfaces. To improve the transformation efficiency, an overnight bacterial culture and low $\mathrm{pH}$ (5.0) medium was used during co-cultivation, thus resulting in the fact that a large amount of Agrobacterium enter the cotyledon explants as compared to the co-cultivation medium with $\mathrm{pH} 5.8$. We observed that there was a few amount Agrobacterium on the interface between cotyledon explants and medium. Also, we found that after cocultivation, the elimination of the bacterium was the key of successful regeneration. Therefore, after several preliminary experiments, $500 \mathrm{mg} / \mathrm{l}$ claforan was considered as the useful concentration for eliminating the bacterium. Currently, $500 \mathrm{mg} / \mathrm{l}$ claforan or carbenicillin were used to control the growth of Agrobacterium (Vallés and Lasa, 1994 and Guis et al., 2000). It was necessary to transfer cotyledon explants to new medium containing $500 \mathrm{mg} / \mathrm{l}$ claforan after three-day co-cultivation. These results are consistent with that found by Vallés and Lasa (1994) but different from that used by

Fayoum J. Agric. Res. \& Dev., Vol. 20, No. 2, July, 2006 
AGROBACTERIUM TUMEFACIENS-MEDIATED

Fang and Grumet (1990). Even though, we also found due to the effects of light and temperature on claforan, its function period was about two weeks, therefore, the explants were transferred to new medium every two weeks, this was an effective way to control the Agrobacterium.

Regeneration of transgenic shoots (herbicide, glufosinat ammonium resistance) under selective conditions:

In order to develop an efficient selection system for muskmelon, the sensitivity of muskmelon cotyledon pieces explant to the herbicide for shoot regeneration was investigated. As shown in Table 3, high concentration of glufosinat ammonium (more than $3 \mathrm{mg} / \mathrm{l}$ ) had an effect not only on shoot formations, but also killed all the cotyledon explant pieces. Low concentration, like $1 \mathrm{mg} / \mathrm{l}$ lacked the capability to select transgenic shoots. Furthermore, experiments indicated that, explants grew better and produced more shoots under the condition of $1 \mathrm{mg} / \mathrm{l}$ glufosinat ammonium, and did not die yet in $3 \mathrm{mg} / \mathrm{l}$ glufosinat ammonium. Similar results were obtained by Toldi et al., (2000) who developed a novel procedure to produce rice tolerant to the herbicide phosphinothricin by means of in vitro selection. When microshoots differentiation were evaluated on the basis of the number of plants regenerated on each explant after 1 month of incubation. They found that the significant effectiveness of microshoots development on induction medium supplemented with $2.0 \mathrm{mg} / \mathrm{l}$ phosphinothricin was mostly due to the fact that the process of differentiation was prolonged. The plantlet explants died after about 1 month of stagnation if concentrations of phosphinothricin higher than $3 \mathrm{mg} / \mathrm{l}$ were applied. Our results are in agreement also with that obtained by Wu et al., (2003) who used 2-4 mg/l phosphinothricin for regeneration and selection of wheat. They suggested that the application of late phosphinothricin selection during the second round of regeneration combined with leaf GUS expression screening proved to be effective in identifying transgenic plants. Also, Iser et al., (1999) used $5 \mathrm{mg} / \mathrm{l}$ phosphinothricin for regeneration and selection of German wheat, shoot development was achieved on R1-medium supplemented with $5 \mathrm{mg} / \mathrm{l}$ phosphinothricin. Little differences were observed between the present results and those of Iser et al., (1999) and Wu et al., (2003). This may be due to different genotypes used in other plant families. Successful transformation also required the optimum concentration of selective agents. So, in our experiments, glufosinat ammonium was used as $3 \mathrm{mg} / \mathrm{l}$ concentration to select transformed tissue with phosphinothricin acetyl transferase (bar) gene (Fig. 2). Also, we found that cells at different stages possessed different tolerance to glufosinat ammonium. Glufosinat ammonium had a detrimental effect on regeneration. Young infected cells were more sensitive than others. On the basis of our experiments, the regenerated shoots from co-cultivated cotyledons with Agrobacterium died under the condition of higher concentration more than $3 \mathrm{mg} / \mathrm{l}$ glufosinat ammonium. Therefore, we used glufosinat ammonium step by step from low to high concentration, that was, from 1 to $3 \mathrm{mg} / \mathrm{l}$.

Fayoum J. Agric. Res. \& Dev., Vol. 20, No.2, July, 2006 
Eissa Ahmed Eissa

Table 3. Frequency of shoot differentiation on selective MS medium containing (1.05 $\mathrm{mg} / \mathrm{l} \mathrm{IAA}+0.6 \mathrm{mg} / \mathrm{l} \mathrm{BA}+0.24 \mathrm{mg} / \mathrm{l} \mathrm{ABA}$ ), and different concentrations of herbicide, glufosinat ammonium (30 days after co-cultivations).

\begin{tabular}{|c|c|c|c|c|}
\hline $\begin{array}{c}\text { Herbicide } \\
\text { con./l }\end{array}$ & $\begin{array}{c}\text { Number of } \\
\text { explants }\end{array}$ & $\begin{array}{c}\text { Number of } \\
\text { explants with } \\
\text { callus formations }\end{array}$ & $\begin{array}{c}\text { Number of explants } \\
\text { with shoot } \\
\text { formations }\end{array}$ & $\begin{array}{c}\text { Number of } \\
\text { dead explants }\end{array}$ \\
\hline $0 \mathrm{mg} / 1$ & 45 & 34 & 20 & 2 \\
$1 \mathrm{mg} / 1$ & 45 & 32 & 14 & 5 \\
$2 \mathrm{mg} / 1$ & 45 & 18 & 9 & 16 \\
$3 \mathrm{mg} / 1$ & 45 & 7 & 6 & 32 \\
$4 \mathrm{mg} / 1$ & 45 & 0 & 0 & 45 \\
$5 \mathrm{mg} / 1$ & 45 & 0 & 0 & 45 \\
$8 \mathrm{mg} / 1$ & 45 & 0 & 0 & 45 \\
$10 \mathrm{mg} / 1$ & 45 & 0 & 0 & 45 \\
\hline
\end{tabular}

Confirmation of transformation (GUS assay):

GUS expression was examined by histochemical assays of calli or young leave tissues. About $16 \mathrm{~h}$ after incubation in 5-bromo-4-chloro-3indolyl glucuronide (X-Gluc), strongly blue staining was obtained in the tissues (Fig. 3). Reporter gene $\beta$-glucuronidase (gusA) as GUS expression have been confirmed by staining of the transformed tissues. Similar finding reported by Vallés and Lasa (1994) in Cucumis melo L.

In conclusion, the present work offer a highly efficient regeneration system for muskmelon using cotyledon pieces as explant was described. An efficient method has been developed to regenerate muskmelon, the cultivar Hales Best Jumbo from in vitro culture. Regeneration from cotyledon pieces of the Hales Best Jumbo was the best by placing 4-day-old explants on an MS medium supplemented with $(1.05 \mathrm{mg} / \mathrm{l} \mathrm{IAA}+0.6 \mathrm{mg} / \mathrm{l} \mathrm{BA}+0.24 \mathrm{mg} / \mathrm{l}$ ABA). An efficient system for regeneration from cotyledon explants can be useful in genetic transformation studies. We have established a transformation system for Hales Best Jumbo by combining the best method of regeneration with $A$. tumefaciens as a vector. More than $3 \mathrm{mg} / \mathrm{l}$ concentration of glufosinat ammonium for selection medium had an effect on shoot formations and killed all the cotyledon explants. Although this cultivar was the only cultivar tested, as the regeneration and transformation systems, the results are considered to be significant steps in the development of commercial transgenic muskmelon cultivars.

\section{Acknowledgements}

The author would like to thank the Vegetable Crop Research Institute, Budatétény, Hungary for providing the plant materials. Also many thanks to Prof. István Velich and Dr. György Bisztray, Dept. of Genetics and Hort. Plant Breeding, Faculty of Hort. Sci., Szent István Univ., Budapest, Hungary, for the laboratory facilities. Special thanks go to Dr. István Nagy, Agric. Biotechnology Center, Gödöllö, Hungary for providing the bacterial strain. I am also grateful to Mrs. Gyurcsáné Millei Ágnes for skilful technical assistance.

Fayoum J. Agric. Res. \& Dev., Vol. 20, No. 2, July, 2006 
AGROBACTERIUM TUMEFACIENS-MEDIATED..

106

Fig. 1

Fayoum J. Agric. Res. \& Dev., Vol. 20, No.2, July, 2006 
Fig. 2,3

Fayoum J. Agric. Res. \& Dev., Vol. 20, No. 2, July, 2006 


\section{REFERENCES}

Bársony, C.; Bisztray, G.; Bába, E. and Velich, I. (1999): Shoot induction and plant regeneration from cotyledon segments of the muskmelon variety "hógolyó". I. J. Hort. Sci. 5: 61-64.

Bordas, M.; Montesinos, C.; Dabauza, M.; Salvador, A.; Roig, L.; Serrano, R. and Moreno, V. (1997): Transfer of the yeast salt tolerance gene HAL1 to Cucumis melo L. cultivars and in vitro evaluation of salt tolerance. Transgenic Research. 6: 41-50.

Debeaujon, I. and Branchard, M. (1991): Somatic embryogenesis and organogenesis from protoplast-derived cultures of muskmelon (Cucumis melo L.). Acta Hort. 289: 225-227.

Ezura, H. and Oosawa, K. (1994): Ploidy of somatic embryos and the ability to regenerate plantlets in melon (Cucumis melo L.). Plant Cell Rep. 14: 107-111.

Fang, G. and Grumet, R. (1990): Agrobacterium-tumefaciences mediated transformation and regeneration of muskmelon plants. Plant Cell Rep. 9: $160-164$.

Gaba, V.; Elman, C.; Perl-Treves, R. and Gray, D.J. (2000): A suggestion for the genetic variability in the ability of Agrobacterium to transform Cucumis melo L. pp: 172-178. Cucurbits Towards 2000, edited by Estación Experimental "La Mayora", C.S.I.C. 29750 Algarrobo, Málaga, Spain.

Gonsalves, C.; Xue, B.; Yepes, M.; Ling, K.; Namba, S.; Chee, P.; Slightom, J. and Gonzalves, D. (1994): Transferring cucumber mosaic virus-white leaf strain coat protein gene into Cucumis melo L. and evaluating transgenic plants for protection against infections. J. Amer. Soc. Hort. Sci. 119: 345-355.

Guis, M.; Botondi, R.; Ayub, R.; Ben Amor, M.; Guillen, P. Latché, A.; Bouzayen, M.; Pech, J.; Dogimont, C.; Pitrat, M.; Leliévre, J. and Albagnac, G. (2000): Physiological and biochemical evaluation of transgenic cantaloupe charentais melons with reduced levels of ACC oxidase. pp: 194-199. Cucurbits Towards 2000, edited by Estación Experimental "La Mayora”, C.S.I.C. 29750 Algarrobo, Málaga, Spain.

Hellens, R.; Mullineaux, P. and Klee, H. (2000): Technical focus, a guide to Agrobacterium binary Ti vectors. Trends in Plant Sci. Update. 5 (10): 446-451.

Hinchee, M.; Padgette, S.; Kishore, G.; Delannay, X. and Fraley, R. (1993): Herbicide-tolerant crops. In: Kung, S.; Wu, R. (eds) Transgenic plants, Vol 1. Academic Press, New York, pp 243-263.

Iser, M.; Fettig, S.; Scheyhing, F.; Viertel, K. and Hess, D. (1999): Genotype-dependent stable genetic transformation in German spring wheat varieties selected for high regeneration potential. J. Plant Physiol. 154: 509-516.

Jefferson, R.A.; Kavanagh, T.A. and Bevan, M.W. (1987): GUS fusions: $\beta$-glucuronidase an versatile gene fusion marker in higher plants. EMBO J. 6: 3901-3907.

Kathal, R.; Bhatnagar, S. and Bhojwani, S. (1986): Regeneration of shoots from hypocotyls callus of Cucumis melo cv. Pusa sharbati. J. Plant Physiol. 126: 59-62.

Fayoum J. Agric. Res. \& Dev., Vol. 20, No.2, July, 2006 
Lichtenstein, C. and Draper, J. (1986): Genetic engineering of plants. pp 67-119 in: DNA Cloning: A Practical Approach. Vol. II. D.M. Glover, ed. IRL Press, Oxford.

Mackay, W.A.; Ng, T.J. and Hammerschlag, F.A. (1989): Direct and indirect regeneration of Cucumis melo from cotyledon culture. Cucurbit Genetics Coop. 12: 55-57.

Moreno, V.; Garcia-Sogo, M.; Granell, I.; Garcia-Sogo, B. and Roig, L. (1985): Plant regeneration from calli of melon (Cucumis melo L., cv. Amarillo Oro). Plant Cell, Tissue and Organ Culture. 5: 139-146.

Murashige, T. and Skoog, F. (1962): A revised medium for rapid growth and bioassays with tobacco tissue cultures. Physiol. Plant. 155: 473497.

Nadolska-Orczyk, A.; Orczyk, W. and Przetakiewicz, A. (2000): Agrobacterium-mediated transformation of cereals-from technique development to its application. Acta Physiol. Plant. 22: 77-88.

Niedz, R.P.; Smith, S.S.; Dunbar, K.V.; Stephens, C.T. and Murakishi, H.H. (1989): Factors influencing shoot regeneration from cotyledonary explants of Cucumis melo. Plant Cell, Tissue and Organ Culture. 18: 313-319.

Orts, M.; Garcia-Sogo, B.; Roche, M.; Roig, L.andMoreno, V. (1987): Morphogenetic response of calli from primary explants of diverse cultivars of melon. HortSci. 22: 666.

Szalai, J. (1996): Micropropagation of muskmelon. Proceeding of the first Egyptian-Hungarian hort. conference. Kafr El-Sheikh, Egypt. 15-17 Sep., 1996, Vol. 1: 102-105.

Toldi, O.; Tóth, S.; Oreifig, A.; Kiss, E. and Jenes, B. (2000): Production of phosphinothricin-tolerant rice (Oryza sativa L.) through the application of phosphinothricin as growth regulator. Plant Cell Rep. 19: $1226-1231$

Vallés, M.P. and Lasa, J.M. (1994): Agrobacterium-mediated transformation of commercial melon (Cucumis melo L., cv. Amarillo Oro). Plant Cell Rep. 13: 145-148.

Wu, H.; Sparks, C.; Amoah, B. and Jones, H. (2003): Factors influencing successful Agrobacterium-mediated genetic transformation of wheat. Plant Cell Rep. 21: 659-668.

Yadav, R.; Saleh, M. and Grummet, R. (1996): High frequency shoot regeneration from leaf explants of muskmelon. Plant Cell, Tissue and Organ Culture. 45 (3): 207-214.

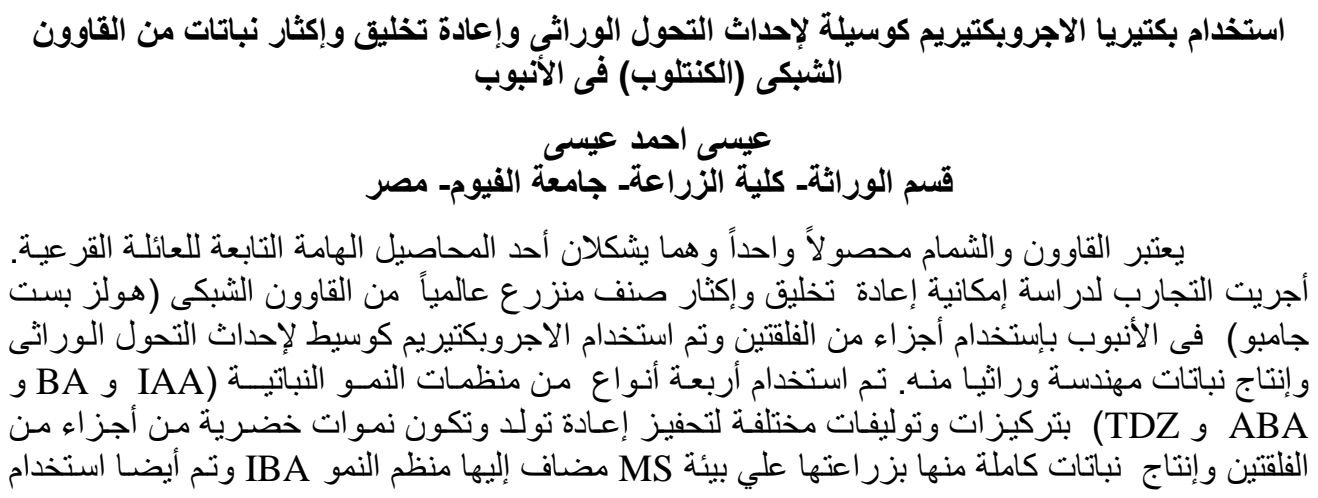

Fayoum J. Agric. Res. \& Dev., Vol. 20, No. 2, July, 2006 
هذه الطريقة فى إنتاج نباتات معدلة ور اثيـا ومقاومـة لأحد مبيدات الحشائش باستخدام الاجروبكتيريم كناقل

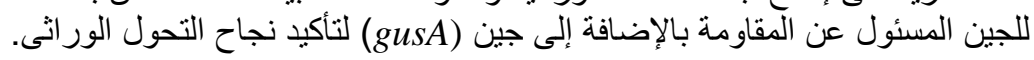

وكاتت أهم النتائج المتحصل عليها ما يلي:

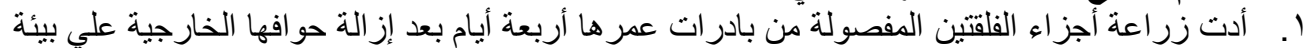

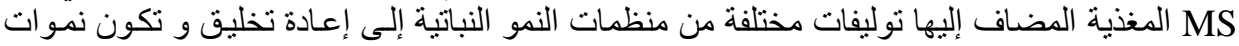
خضرية منها.

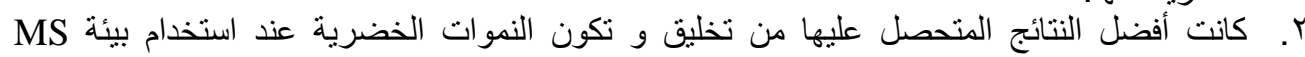

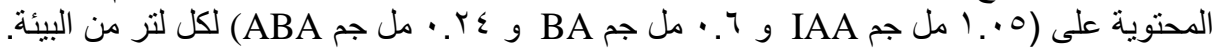

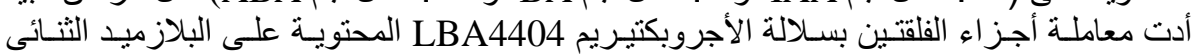

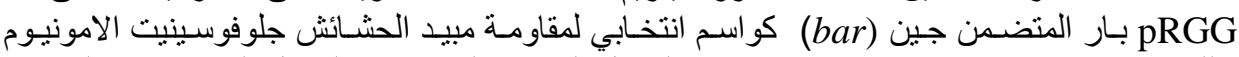

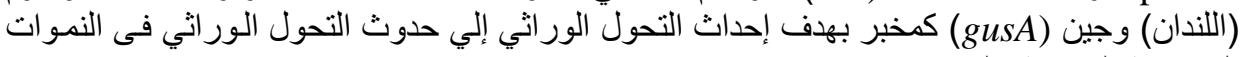
الخضرية المتكونة عليها.

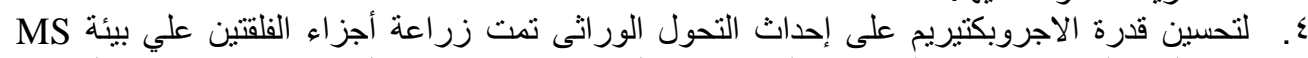

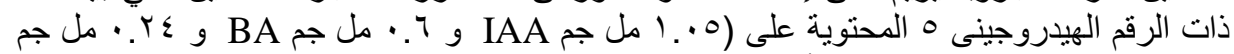

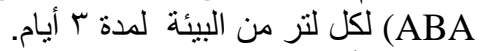

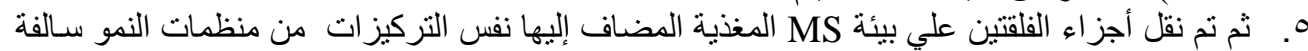

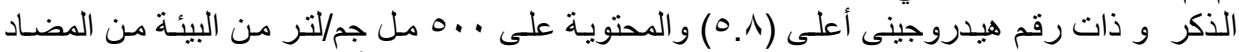

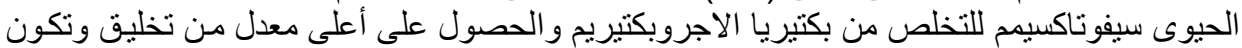
نموات خضرية معدلة ور اثيا.

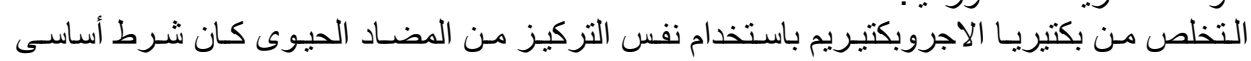

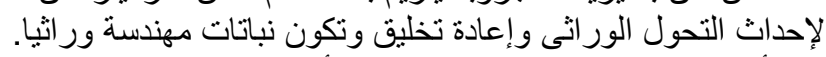

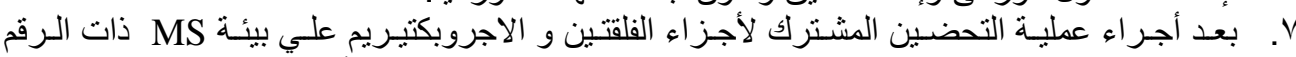

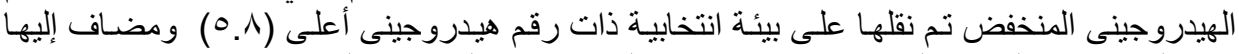

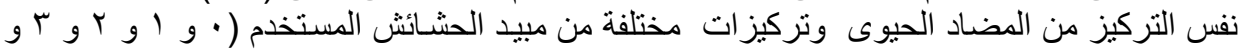

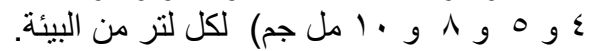

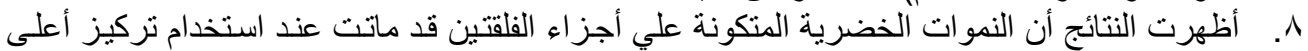

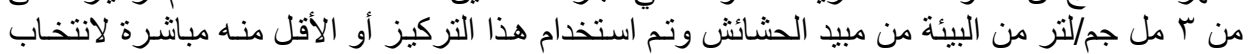
النموات الخضرية المعدلة ور اثنيا.

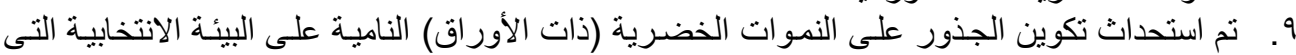

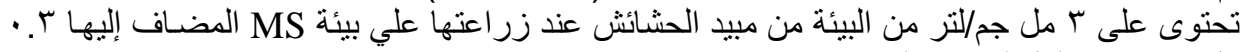

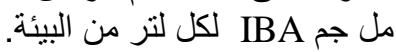
• 1. نم تأكيد حدوث التحول الور اثى في القاوون الثبكى بالاختبار المستخدم فى الكثف عن عن تعبير جين (gusA)

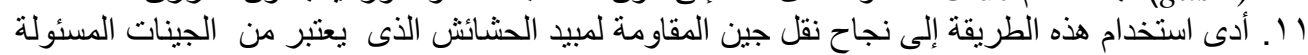

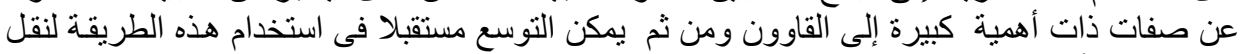
جينات هامة أخرى إليه. - اتهير 

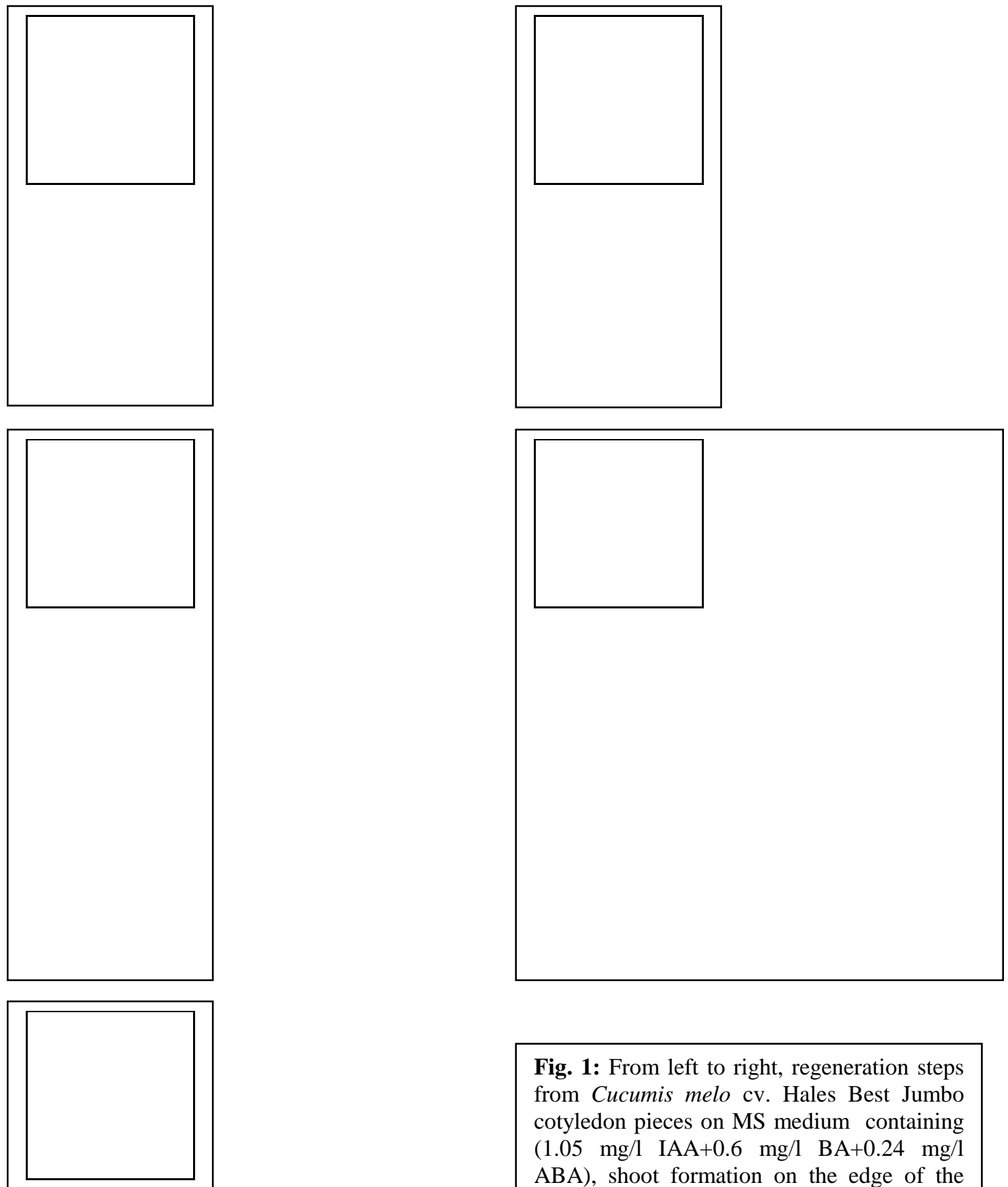

Fig. 1: From left to right, regeneration steps from Cucumis melo cv. Hales Best Jumbo cotyledon pieces on MS medium containing (1.05 mg/l IAA+0.6 mg/l BA+0.24 mg/l ABA), shoot formation on the edge of the pieces.

Fayoum J. Agric. Res. \& Dev., Vol. 20, No. 2, July, 2006 


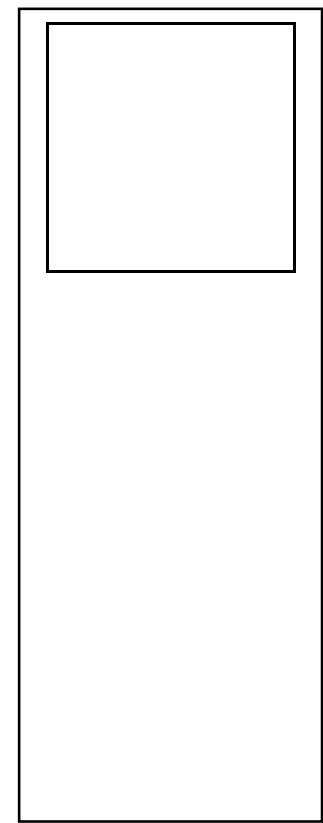

Fig. 2: Transgenic muskmelon shoots growing on clean selective MS regeneration medium contained $3 \mathrm{mg} / \mathrm{l}$ glufosinat ammonium as selective agent.

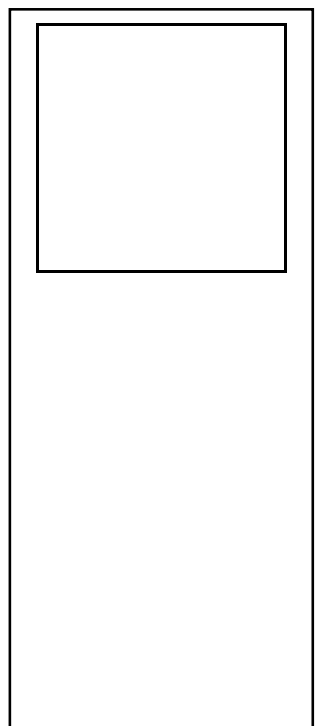

Fig. 3: Stable expression of gusA gene and GUS-assay showing $\beta$-glucuronidase activity in the muskmelon tissues that stained blue with X-Gluc assay, while control not showed a positive reaction.

Fayoum J. Agric. Res. \& Dev., Vol. 20, No.2, July, 2006 